\title{
Bronchoalveolar Lavage Fluid Findings in the Atelectatic Regions of Anesthetized Horses
}

\author{
Shinobu $\mathrm{ITO}^{1) *}$, Seiji $\mathrm{HOBO}^{2)}$ and Yoshinori KASASHIMA ${ }^{2)}$ \\ ${ }^{1)}$ Ritto Training Center, Japan Racing Association, 1028 Misono, Ritto-shi, Shiga 520-3085 and ${ }^{2)}$ Equine Research Institute, Japan \\ Racing Association, 321-4 Tokami-cho, Utsunomiya-shi, Tochigi 320-0856, Japan
}

(Received 5 December 2001/Accepted 15 May 2003)

ABSTRACT. To evaluate the effects of compression atelectasis on the composition of pulmonary secretions in anesthetized horses, cytological and biochemical examinations were performed on bronchoalveolar lavage (BAL) fluids obtained from both dependent and independent lung regions. Six horses were anesthetized with isoflurane and oxygen for $120 \mathrm{~min}$, and were positioned in right lateral recumbency. Percentage of neutrophils and total protein concentration in BAL fluids significantly increased at the end of anesthesia, and total phosphorous concentration significantly decreased at $72 \mathrm{hr}$ after anesthesia in dependent lung. Such changes were not observed within 168 $\mathrm{hr}$ after anesthesia. These findings suggest that the effects of compression atelectasis on the composition of pulmonary secretions may be eliminated within $168 \mathrm{hr}$ after anesthesia.

KEY WORDS: atelectasis, equine, pulmonary secretion.

J. Vet. Med. Sci. 65(9): 1011-1013, 2003

Compression atelectasis is considered as the cause of both the impaired gas exchange during anesthesia [11] and post anesthetic pulmonary disease [12] in horses. However, none have mentioned the effects of the atelectasis on the pulmonary secretions in horses. In addition, it is not clear whether an interval of 7 days in the anesthetic design is warranted under laboratory conditions.

Pulmonary surfactant plays an important role in mucociliary clearance, antimicrobial activity and immune regulation as well as in alveolar stability [8]. It is well known that major component of pulmonary surfactant is phospholipids [2], and the proteins in the pulmonary edema fluid have a potential to inactivate pulmonary surfactant [10]. To obtain data on the effects of the atelectasis on the pulmonary secretions, we evaluated the phospholipid composition, as well as total protein concentration and differential cell counts of bronchoalveolar lavage (BAL) fluids obtained from both dependent and independent lung regions in laterally recumbent anesthetized horses.

Six mature Thoroughbred horses (4 males and 2 geldings) without a history or clinical signs of respiratory tract disease were studied. The each horse was fasted for 8 to $12 \mathrm{hr}$ before anesthesia, but allowed free access to water. Following a sedation with xylazine $(1.0 \mathrm{mg} / \mathrm{kg}), 10 \%$ guaifenesin solution $(500 \mathrm{ml})$ and thiopental $(4.0 \mathrm{mg} / \mathrm{kg})$ was given intravenously. Immediately after induction, the horses were laid on their right side. Then a cuffed tracheal tube was inserted into the trachea. The horses were anesthetized with isoflurane and oxygen, using anesthetic equipment for large animals (LAVC 2000, J.D.Medical, U.S.A.). End - tidal isoflurane concentration was maintained at $1.5 \pm 0.1 \%$. Intermittent positive pressure ventilation was used to main-

\footnotetext{
* Present address: Ito, S., Epizootic Prevention Section, Equine Department, Japan Racing Association, 11 - 1 Roppongi 6 chome, Minato - ku, Tokyo, 106 - 8401, Japan.
}

tain $\mathrm{PaCO}_{2}$ of $40 \pm 5 \mathrm{mmHg}$. The duration of anesthesia was $120 \mathrm{~min}$. Following the removal of anesthesia, the horses were kept laid on their right side.

BAL was performed $72 \mathrm{hr}$ before anesthesia (first lavage, standing), at the beginning of anesthesia (second lavage, recumbent), at the end of anesthesia (third lavage, recumbent), $72 \mathrm{hr}$ after anesthesia (fourth lavage, standing), and $168 \mathrm{hr}$ after anesthesia (fifth lavage, standing). Each BAL procedure was repeated in the bronchus adjacent to the initial lavage. BAL procedure in standing horses was performed as previously described [6]. BAL procedure in anesthetized horses was as follows. A bronchoscope (300 $\mathrm{cm}$ long, $8.7 \mathrm{~mm}$ diameter) with a $2.0 \mathrm{~mm}$ diameter biopsy channel was introduced into the nostril and advanced beside the cuffed tracheal tube into the lung until it wedged in the second branch of the principal bronchus located laterally in dependent lung. Air from the lavage area was extracted through the bronchoscope biopsy channel by syringe. One hundred $\mathrm{m} l$ of sterile isotonic saline solution $(0.9 \% \mathrm{NaCl}$, $37^{\circ} \mathrm{C}$ ) was infused under pressure through the biopsy channel into the lung and then aspirated slowly. This procedure was repeated 3 times for a total injected volume of $300 \mathrm{ml}$. The bronchoscope was then repositioned in the opposite lung lobes and the procedure was repeated.

After measuring the volume of collected BAL fluids, they were filtrated with sterilized gauze. The fluids were then centrifuged at $500 \times \mathrm{g}$ for $10 \mathrm{~min}$ at $4^{\circ} \mathrm{C}$, to separate them into cellular components and supernatants. The number of total nucleated cells was counted by a leukocyte counter. Differential cell count was determined on the basis of microscopic examination of 200 nucleated cells. Total protein, total phosphorus, and phospholipid concentrations were measured by standard procedures [6].

Date are expressed as mean \pm SEM. Wilcoxon's signed - ranks test was used to determine whether there were significant differences between the composition obtained at base 
line (72 hr before anesthesia) and other times. A Mann Whitney test was used to compare the composition between independent and dependent lungs. A value of $P<0.05$ was considered significant.

Experimental horses remained in good health throughout this study. Hemorrhage was not observed by bronchoscopy in any of the horses. Results of cytologic and biochemical analyses of BAL fluid are shown in Table 1. Statistical differences were not detected between the total nucleated cell counts at base line and at other times. Compared with base line, percentage of neutrophils and total protein concentration at the end of anesthesia significantly increased in dependent lung. These results of dependent lung were significantly higher than those of independent lung. No significant difference was observed in the specimens obtained from independent lung. Total phosphorous concentration at $72 \mathrm{hr}$ after anesthasia significantly decreased from $75.7 \pm$ $15.2 \mathrm{nmol} / \mathrm{m} l$ at base line to $39.8 \pm 9.1 \mathrm{nmol} / \mathrm{m} l$ in dependent lung. Statistical differences were detected between dependent and independent lung at $72 \mathrm{hr}$ after anesthasia. The following 6 types of phospholipids were identified in BAL fluid : phosphatidylcholine, phosphatidylglycerol
(PG), phosphatidylethanolamine, phosphatidylinositol, phosphatidylserine, and sphingomyeline. For the phospholipid concentration, no significant difference was observed in each lung.

Ito et al. [7] observed at necropsy that all of 5 horses under the same anesthetic condition as in this study developed compression atelectasis in dependent lung regions. Therefore, we interpreted that the 6 experimental horses developed compression atelectasis, though none of the horses were available for necropsy.

BAL is a valuable diagnostic method to evaluate various response of the lung cells and secretions in horses [14]. However, Sweeney et al. [15] reported that there was a marked neutrophilic infiltrate in the affected lung segment $48 \mathrm{hr}$ after BAL that resolved by day 7, and the adjacent segment should not be influenced by initial lavage. Therefore, each BAL procedure was performed in the site adjacent to the site affected with the prior BAL procedure throughout this study.

Percentage of neutrophils and total protein concentration at the end of anesthesia significantly increased in dependent lung, but not in independent lung. These findings were sim-

Table 1. Results of cytologic and biochemical analyses of BAL samples obtained from right laterally recumbent anesthetized horses $(n=6)$

\begin{tabular}{|c|c|c|c|c|c|c|}
\hline \multirow[t]{2}{*}{ Variables } & & \multirow{2}{*}{$\begin{array}{l}72 \mathrm{hr} \text { before } \\
\text { anesthesia }\end{array}$} & \multirow{2}{*}{$\begin{array}{l}\text { Beginning } \\
\text { of anesthesia }\end{array}$} & \multirow{2}{*}{$\begin{array}{c}\text { End } \\
\text { of anesthesia }\end{array}$} & \multicolumn{2}{|c|}{ Afteranesthesia } \\
\hline & & & & & $72 \mathrm{hr}$ & $168 \mathrm{hr}$ \\
\hline \multirow{2}{*}{$\begin{array}{l}\text { Return rates } \\
(\%)\end{array}$} & independent & $67.8 \pm 4.3$ & $60.3 \pm 3.2$ & $56.5 \pm 7.1$ & $68.2 \pm 2.1$ & $65.0 \pm 1.0$ \\
\hline & dependent & $65.8 \pm 3.3$ & $53.7 \pm 6.2$ & $53.0 \pm 5.7$ & $68.8 \pm 2.9$ & $66.3 \pm 3.3$ \\
\hline \multirow{2}{*}{$\begin{array}{l}\text { Total nucleated cells } \\
\left(\times 10^{5} \text { cells } / \mathrm{m} l\right)\end{array}$} & independent & $5.0 \pm 1.1$ & $3.4 \pm 0.6$ & $3.8 \pm 0.4$ & $4.4 \pm 1.0$ & $4.7 \pm 0.4$ \\
\hline & dependent & $4.5 \pm 0.8$ & $3.9 \pm 0.7$ & $5.1 \pm 0.6$ & $4.2 \pm 0.8$ & $3.6 \pm 0.2$ \\
\hline \multirow{2}{*}{$\begin{array}{l}\text { Alveolar macrophages } \\
(\%)\end{array}$} & independent & $56.0 \pm 3.5$ & $53.3 \pm 5.3$ & $66.9 \pm 10.5$ & $56.2 \pm 8.9$ & $71.3 \pm 2.9$ \\
\hline & dependent & $58.0 \pm 2.5$ & $65.7 \pm 3.5$ & $59.8 \pm 4.6$ & $55.7 \pm 8.0$ & $69.5 \pm 8.3$ \\
\hline \multirow{2}{*}{$\begin{array}{l}\text { Lymphocytes } \\
(\%)\end{array}$} & independent & $30.0 \pm 5.0$ & $37.9 \pm 5.9$ & $23.2 \pm 4.4$ & $35.3 \pm 5.9$ & $23.7 \pm 4.0$ \\
\hline & dependent & $37.0 \pm 2.3$ & $29.7 \pm 4.0$ & $30.3 \pm 3.8$ & $36.3 \pm 8.2$ & $26.7 \pm 8.1$ \\
\hline \multirow{2}{*}{$\begin{array}{l}\text { Neutrophils } \\
(\%)\end{array}$} & independent & $5.2 \pm 0.2$ & $4.5 \pm 2.8$ & $4.5 \pm 1.3$ & $5.7 \pm 2.5$ & $3.9 \pm 1.2$ \\
\hline & dependent & $4.7 \pm 1.5$ & $4.7 \pm 2.2$ & $9.5 \pm 2.3^{\mathrm{a}, \mathrm{b})}$ & $7.8 \pm 1.1$ & $3.8 \pm 1.0$ \\
\hline \multirow{2}{*}{$\begin{array}{l}\text { Eosinophils } \\
(\%)\end{array}$} & independent & $0.0 \pm 0.0$ & $0.2 \pm 0.1$ & $0.0 \pm 0.0$ & $1.8 \pm 1.4$ & $1.8 \pm 1.3$ \\
\hline & dependent & $0.0 \pm 0.0$ & $0.5 \pm 0.3$ & $0.0 \pm 0.0$ & $0.2 \pm 0.1$ & $0.0 \pm 0.0$ \\
\hline Total protein & independent & $320 \pm 36$ & $293 \pm 14$ & $310 \pm 33$ & $378 \pm 41$ & $358 \pm 49$ \\
\hline $\begin{array}{l}\text { concentration } \\
(\mu \mathrm{g} / \mathrm{m} l)\end{array}$ & dependent & $319 \pm 43$ & $405 \pm 91$ & $629 \pm 99^{\mathrm{a}, \mathrm{b})}$ & $357 \pm 22$ & $344 \pm 38$ \\
\hline \multirow{2}{*}{$\begin{array}{l}\text { Total Phosphorus } \\
(\mathrm{n} \mathrm{mol} / \mathrm{m} l)\end{array}$} & independent & $70.8 \pm 16.3$ & $64.5 \pm 6.0$ & $62.1 \pm 13.4$ & $60.6 \pm 6.6$ & $64.9 \pm 6.2$ \\
\hline & dependent & $75.7 \pm 15.2$ & $75.7 \pm 13.0$ & $70.2 \pm 17.9$ & $39.8 \pm 9.1^{\mathrm{a}, \mathrm{b})}$ & $67.1 \pm 12.6$ \\
\hline \multirow{2}{*}{$\begin{array}{l}\text { Phosphatidylcholine } \\
\text { (\%) }\end{array}$} & independent & $77.9 \pm 8.2$ & $79.6 \pm 11.1$ & $77.9 \pm 13.3$ & $79.4 \pm 11.9$ & $79.9 \pm 10.1$ \\
\hline & dependent & $79.3 \pm 13.2$ & $80.9 \pm 6.7$ & $77.6 \pm 8.6$ & $80.1 \pm 5.7$ & $79.4 \pm 8.9$ \\
\hline \multirow{2}{*}{$\begin{array}{l}\text { Phosphatidylglycerol } \\
(\%)\end{array}$} & independent & $11.2 \pm 1.2$ & $11.4 \pm 3.8$ & $10.7 \pm 5.1$ & $11.7 \pm 2.2$ & $7.5 \pm 3.1$ \\
\hline & dependent & $11.8 \pm 1.6$ & $9.1 \pm 3.1$ & $10.8 \pm 1.6$ & $11.3 \pm 0.3$ & $7.9 \pm 1.9$ \\
\hline \multirow{2}{*}{$\begin{array}{l}\text { Phosphatidylethanolamine } \\
(\%)\end{array}$} & independent & $2.6 \pm 1.5$ & $2.6 \pm 1.5$ & $3.4 \pm 2.9$ & $2.3 \pm 2.2$ & $3.2 \pm 1.6$ \\
\hline & dependent & $2.3 \pm 1.7$ & $2.3 \pm 1.4$ & $3.2 \pm 2.2$ & $2.2 \pm 2.0$ & $3.4 \pm 1.2$ \\
\hline \multirow{2}{*}{$\begin{array}{l}\text { Phosphatidylinositol } \\
\text { (\%) }\end{array}$} & independent & $3.8 \pm 1.5$ & $3.2 \pm 2.3$ & $3.6 \pm 4.2$ & $3.7 \pm 1.7$ & $3.8 \pm 2.2$ \\
\hline & dependent & $3.9 \pm 2.1$ & $3.5 \pm 1.1$ & $3.9 \pm 2.2$ & $3.4 \pm 1.1$ & $3.6 \pm 1.5$ \\
\hline \multirow{2}{*}{$\begin{array}{l}\text { Phosphatidylserine } \\
(\%)\end{array}$} & independent & $1.9 \pm 0.8$ & $1.4 \pm 1.0$ & $1.7 \pm 0.8$ & $1.1 \pm 0.2$ & $1.9 \pm 0.9$ \\
\hline & dependent & $1.2 \pm 0.8$ & $1.2 \pm 0.8$ & $1.9 \pm 0.4$ & $1.2 \pm 0.8$ & $2.5 \pm 1.1$ \\
\hline \multirow{2}{*}{$\begin{array}{l}\text { Sphingomyelin } \\
(\%)\end{array}$} & independent & $1.5 \pm 0.7$ & $0.9 \pm 0.6$ & $1.2 \pm 0.3$ & $1.1 \pm 0.9$ & $2.1 \pm 0.8$ \\
\hline & dependent & $0.8 \pm 0.4$ & $1.0 \pm 0.6$ & $1.5 \pm 0.9$ & $1.1 \pm 0.4$ & $1.8 \pm 0.7$ \\
\hline \multirow{2}{*}{$\begin{array}{l}\text { Unknown } \\
(\%)\end{array}$} & independent & $1.1 \pm 0.3$ & $1.0 \pm 0.9$ & $1.6 \pm 0.8$ & $0.7 \pm 0.2$ & $1.6 \pm 0.9$ \\
\hline & dependent & $0.7 \pm 0.5$ & $1.9 \pm 0.7$ & $1.1 \pm 0.4$ & $0.7 \pm 0.5$ & $1.5 \pm 0.5$ \\
\hline
\end{tabular}

a) Significantly $(P<0.05)$ different from value at base line (before anesthesia).

b) Significantly $(P<0.05)$ different from value at independent lung.

Date are expressed as mean \pm SEM. 
ilar to the previous report that there was a direct correlation between the percentage of lavage neutrophils and lung protein permeability in the form of adult respiratory distress syndrome [16]. In addition, it is recognized that neutrophil influx accompanies non- infectious inflammatory airway disease (IAD)[9]. Therefore, these findings are potentially suggestive of IAD at the end of anesthesia in dependent lung.

To maintain alveolar stability and gas exchange, pulmonary surfactant must lower alveolar surface tension. This activity of pulmonary surfactant is known to be impeded by the protein components in plasma [1]. We interpreted that the increase in total protein concentration in dependent lung was due to the fact that plasma components leaked into the alveolar cavity as the membrane properties of the alveolar cavity and blood capillaries changed [3]. Therefore, although total phosphorus concentration did not significantly decrease during anesthesia, the protein components in the alveolar cavity may impede the activity of pulmonary surfactant. Consequently, the protein components in the alveolar cavity might be one of the reasons for gas exchange impairment commonly seen in anesthetized horses.

Pulmonary surfactant is synthesized and secreted by alveolar type II epithelial cells [5]. In most species, pulmonary surfactant has a half-life of approximately $14 \mathrm{hr}$ [2], and PG is found primarily in pulmonary tissue $[5,13]$. Therefore, the decrease in PG concentration accompanied with the decrease in total phosphorus concentration at $72 \mathrm{hr}$ after anesthesia indicates a reduction in the quantity of surfactant. This change may reflect either a decreased production of surfactant by alveolar type II epithelial cells or an increased removal of surfactant from the alveolar region. Although general anesthesia by inhalants is known to depress normal mucociliary clearance mechanisms [4], the decrease in pulmonary surfactant in dependent lung may reduce the pulmonary defence mechanisms. Such a decrease should be considered as one of the causes of postanesthetic pulmonary diseases. Further examination of BAL fluids obtained from postanesthetic pulmonary disease is necessary.

In conclusion, compression atelectasis effects on percent- age of neutrophils, total protein concentration and amount of pulmonary surfactant in BAL fluids, and these effects may be eliminated within $168 \mathrm{hr}$ after anesthesia. These data warrant an interval of 7 days in the anesthetic design under laboratory conditions.

ACKNOWLEDGEMENTS. We would like to thank Drs. M. Oikawa and K. Yashiki, Japan Racing Association, Equine Research Institute, for their helps in preparing this manuscript and biochemical assistance.

\section{REFERENCES}

1. Berry, D., Ikegami, M. and Jobe, A. 1986. J. Appl. Physiol. 61: 1741-1748.

2. Derksen, F.J. 1991. pp. 1-25. In: Equine Respiratory Disorders (Beech,J. ed.), Lea \& Febiger, Philadelphia.

3. Dreyfuss, D., Solar, P. and Basset, G. 1988. Am. Rev. Respir. Dis. 137: 1159-1164.

4. Forbes, A.R. and Gamsu, G. 1979. Anesth. Analg. 58: 387389.

5. Goerke, J. 1974. Biochem. Biophys. Acta 344: 241-261.

6. Hobo, S., Oikawa, M., Kuwano, A., Yosida, K. and Yoshihara, T. 1997. Am. J. Vet. Res. 58: 531-534.

7. Ito, S., Ishimaru, M., Hobo, S. and Fujinaga, T. 1996. J. Vet. Med. Sci. 58: 1205-1209.

8. Jobe, A.H. and Jacob, H.C. 1984. p. 271. In: Pulmonary Surfactant (Robertson, B. ed), Elsevier. Amsterdam.

9. Moore, B.R., Krakowka, S., Robertson, J.T. and Cummis, J.M. 1995. Am. J. Vet. Res. 56: 562-567.

10. Nitta, K. and Kobayashi, T. 1994. Respir. Physiol. 95: 43-51.

11. Nyman, G., Funkuist, B. and Kvart, C. 1990. Equine Vet. J. 22: 317-324.

12. Raphel, C.F. and Beech, J. 1982. J. Am. Vet. Med. Assoc. 181: 808-810.

13. Rooney, S.A. 1985. Am. Rev. Respir. Dis. 131: 439-460.

14. Sweeney, C.R.and Beech, J. 1991. pp. 55-61. In: Equine Respiratory Disorders (Beech, J. ed), Lea \& Febiger. Philadelphia.

15. Sweeney, C.R., Rossier, Y., Ziemer, E.L. and Lindborg, S.R. 1994. Am. J.Vet. Res. 55: 1501-1504.

16. Weiland, J.E., Davis, W.B., Holter, J.F., Mohammed, J.R., Dorinsky, P.M. and Gadek, J.E. 1986. Am. Rev. Respir. Dis. 133: $218-225$. 